\title{
POLITIK DISTRIBUTIF DALAM KEBIJAKAN HIBAH PROVINSI BANTEN \\ STUDI KASUS : DISTRIBUSI DANA HIBAH KESEJAHTERAAN RAKYAT (KESRA) DI PROVINSI BANTEN TAHUN 2019
}

\author{
Muhammad Ibrahim Rantau, Ahmad Murodi, Amin Fendi Rahmelan, \\ dan Irvan Arif Kurniawan \\ Universitas Islam Syekh Yusuf Tangerang \\ ibrahimrantau2013@gmail.com, amurodi@unis.ac.id, 1601010103@students.unis.ac.id
}

iakurniawan@unis.ac.id

\begin{abstract}
ABSTRAK
Beberapa studi tentang distribusi sumber daya negara di Provinsi Banten menunjukkan bahwa kerap terjadi politik distributif dalam distribusi hibah dan bansos dengan berbagai pola, terutama pola pork barrel, dimana distribusi hibah dan bansos dilakukan dengan pertimbangan politik balas budi pasca kontestasi politik. Penelitian ini hendak menindak lanjuti beberapa temuan dalam studi sebelumnya tentang kecenderungan politik distributif dalam distribusi hibah dan bansos di Provinsi Banten. Penelitian ini ingin memfokuskan studi pada pola politik distributif dalam distribusi hibah Kesejahteraan Rakyat (Kesra) di Provinsi Banten pada tahun 2019. Penelitian dilakukan dengan metode kualitatif dengan cara menganalisis data-data primer yang didapatkan, dan melakukan wawancara mendalam dengan narasumber yang dibutuhkan. Penelitian ini kemudian menemukan pola baru dalam distribusi hibah Kesejahteraan Rakyat Provinsi Banten tahun 2019, yang berbeda dengan pola yang ditemukan dalam beberapa penelitian sebelumnya.

Kata Kunci : Politik Distributif, Kebijakan, Hibah Provinsi
\end{abstract}

\section{ABSTRACT}

Several studies on the distribution of state resources in Banten Province show that there are often distribution politics in the distribution of grants and social assistance with various patterns, especially the pig barrel pattern, in which the distribution of grants and prohibitions is carried out with political considerations in response to political contestation. This study developed several findings from previous studies on political trends in the distribution of grants and social assistance in Banten Province. This research wants to focus on the study of political distribution patterns in the distribution of People's Welfare (Kesra) grants in Banten Province in 2019. The research was conducted using a qualitative method by analyzing the primary data obtained and conducting indepth interviews with the required sources. This study then found a new pattern in the distribution of the 2019 Banten Province People's Welfare grants, which was different from the pattern found in several previous studies.

Keywords: Distributive Politics, Policy, Provincial Grants

\section{A. PENDAhuluan}

Salah satu program pemerintah yang peruntukan dan distribusinya langsung kepada masyarakat, baik melalui individu, keluarga, masyarakat, maupun kepada instansi/lembaga masyarakat lainnya adalah Hibah dan Bantuan Sosial (Bansos). Dalam Permendagri No 32 tahun 2011, tentang pedoman pemberian Hibah dan Bansos, yang dimaksud dengan Hibah adalah pemberian dan pemerintah daerah, kepada pemerintah daerah lain, perusahaan daerah, masyarakat, dan ormas. Sedangkan bansos adalah pemberian dari pemerintah daerah kepada individu, keluarga, 
kelompok, atau masyarakat. ${ }^{1}$ Kedua program ini merupakan salah satu bentuk pelaksanaan kewajiban negara dalam rangka meningkatkan kesejahteraan rakyat, dimana dalam penggunaan dan distribusinya harus sesuai dengan aturan perundang undangan yang berlaku.

Namun dalam pelaksanaannya, distribusi program Hibah dan Bansos kerap kali dibumbui dengan muatan dan kepentingan kontestasi politik, baik di level nasional maupun politik lokal. Penyaluran Hibah dan Bansos yang seharusnya berbasis kebutuhan dan kesejahteraan masyarakat, justru lebih sarat dengan muatan politik. Dalam praktiknya, pembagian Bansos dan Hibah sering disertai dengan pesan pesan kampanye para kontestan politik, sehingga distribusi hibah dan bansos menjadi bias kepentingan politik. Akibatnya, pelaksanaan hibah dan bansos kerap diwarnai dengan penyalahgunaan dan penyelewengan baik dalam proses penentuan alokasi, distribusi, pelaksanaan, maupun pertanggung jawaban dan laporan pelaksanaan.

Kasus penyelewengan dana hibah dan bansos kerap kali terjadi di berbagai wilayah. Beberapa diantaranya menjadi head line berita nasional karena melibatkan kepala daerah secara langsung, seperti korupsi Bansos Kota Pontianak tahun 2006-2008, korupsi Bansos Kabupaten Lampung Tengah tahun 2007, korupsi dana Bansos Kota Bandung tahun 2009 yang menyeret mantan Walikota Bandung, Dada Rosada, korupsi Bansos Kota Kendal tahun 2010, termasuk korupsi Hibah dan Bansos Provinsi Banten tahun 2011. Kasus terbaru adalah korupsi dana hibah Kabupaten Tasikmalaya, yang merugikan negara hingga 3,9 miliar rupiah.

Penyelewengan hibah dan bansos kerap terjadi dalam momen kontestasi politik, karena hibah dan bansos lebih bersifat populis. Kedua program ini berkaitan secara langsung dengan kesejahteraan masyarakat, sehingga dianggap dapat mempengaruhi preferensi dan perilaku politik masyarakat. Potensi penggunaan Hibah dan Bansos untuk kontestasi politik dapat dilihat dari kecenderungan naiknya alokasi dana hibah dan bansos dalam postur anggaran pemerintah, baik APBN maupun APBD. Kenaikan dana bansos dalam APBN dapat dilihat menjelang pemilu 2014, dimana terjadi peningkatan yang cukup signifikan dari 75,6 triliun pada tahun 2012 menjadi 92,1 triliun pada tahun 2013. ${ }^{2}$ Peningkatan dana hibah dan bansos juga terlihat cukup signifikan menjelang pemilu 2019

Tidak hanya dilevel nasional, peningkatan alokasi dana hibah menjelang tahun politik juga banyak terjadi di level lokal. Di Provinsi Banten misalnya, peningkatan alokasi Hibah meningkat hingga 666 miliar pada tahun 2011 atau naik $187 \%$, dibanding tahun 2010 yang hanya sebesar 231 miliar. Demikian juga dengan alokasi dana bansos ditahun yang sama naik sebesar 78 miliar, atau naik hingga $52 \%$ dibanding tahun sebelumnya yang hanya sebesar 51 miliar. ${ }^{3}$ Ditahun 2011 ini pula distribusi dana hibah dan bansos kemudian menjadi salah satu temuan yang menjerat Gubernur Banten ketika itu, Ratu Atut Chosiyah, sebagai tersangka kasus korupsi, disamping operasi tangkap tangan dibeberapa kasus lainnya.

\footnotetext{
${ }^{1}$ Pelaksanaan pemberian Hibah dan Bansos diatur dalam beberapa peraturan perundang undangan, yaitu Peraturan Pemerintah Nomor 2 Tahun 2012 Tentang Hibah Daerah, Peraturan Menteri Keuangan Nomor 99/PMK.05/2017 Tentang Administrasi Pengelolaan Hibah, Permendagri Nomor 32 Tahun 2011 Tentang Pedoman Pemberian Hibah dan Bansos yang bersumber dari APBD, yang telah direvisi dalam Permendagri Nomor 39 Tahun 2012 Tentang Perubahan Pertama Permendagri Nomor 32 Tahun 2011, dan direvisi kembali dalam Permendagri Nomor 14 tahun 2016 Tentang Perubahan Kedua Permendagri Nomor 32 Tahun 2011.

${ }^{2}$ Antonius Saragintan dan Syahrul Hidayat, Politik Pork Barel di Indonesia: Kasus Hibah dan Bantuan Sosial di Provinsi Banten tahun 2011, Jurnal Politik, Vol.2, No 1, Agustus 2016. Hal 139-140.

${ }^{3}$ LKPD Provinsi Banten tahun 2010 dan 2011. Lihat juga dalam Antonius Saragintan dan Syahrul Hidayat, Politik Pork Barel di Indonesia: Kasus Hibah dan Bantuan Sosial di Provinsi Banten tahun 2011, Jurnal Politik, Vol.2, No 1, Agustus 2016. Hal 139-140.
} 
Peningkatan alokasi dana hibah dan bansos menjelang momen politik juga disertai adanya pola distribusi dengan memprioritaskan wilayah yang notabenenya menjadi basis konstituen dari petahana. Alokasi terbanyak yang mendapatkan hibah dan bansos pada tahun 2011 adalah daerah daerah yang menjadi basis suara Ratu Atut pada kontestasi politik sebelumnya, yaitu Pilkada Banten 2006. Dalam pilkada Provinsi Banten 2006, pasangan Ratu Atut dan Muhammad Masduki memenangkan 4 wilayah dari total 6 kabupaten/kota di Provinsi Banten, yakni Kabupaten Serang dengan perolehan suara $37,68 \%$ suara, Kabupaten Tangerang, 38,15\% suara, Kabupaten Pandeglang dengan 42,32\% suara, dan Kabupaten Lebak dengan 52,34\% suara,

Demikian juga dengan hasil Pilkada Provinsi Banten pada tahun 2011 dimana Ratu Atut memenangkan perolehan suara di hampir semua Kapubaten/Kota di Provinsi Banten, kecuali Kota Tangerang. Di Kota Serang, Ratu Atut memenangkan 55,47\%, dari total suara keseluruhan, Kabupaten Serang sebesar 61,13\%, Kabupaten Pandeglang dengan 50,17\% suara, Kabupaten Lebak dengan 57,91\%, Kabupaten Tangerang dengan 48,08\%, sedangkan Kota Tangerang Selatan sebesar 61,09\% suara. Perolehan suara pada kedua Pilkada diatas berbanding lurus dengan sebaran distribusi dana hibah dan bansos yang teridentifikasi sesuai dengan basis konstituen Ratu Atut.

Tabel:1

Akumulasi dan Alokasi Hibah Berbasis Wilayah

\begin{tabular}{|l|l|}
\hline \multicolumn{1}{|c|}{ Kabupaten/Kota } & Alokasi Hibah dalam Rupiah \\
\hline Kota Serang & 22.212 .000 .000 \\
\hline Kabupaten Pandeglang & 8.000 .000 .000 \\
\hline Kabupaten Tangerang & 7.835 .000 .000 \\
\hline Kabupaten Lebak & 7.300 .000 .000 \\
\hline Kabupaten Serang & 3.580 .000 .000 \\
\hline Kota Tangerang Selatan & 3.500 .000 .000 \\
\hline Kota Cilegon & 500.000 .000 \\
\hline Kota Tangerang & 2.950 .000 .000 \\
\hline
\end{tabular}

Forum Indonesia Untuk Transparansi Anggaran (FITRA) yang melakukan penelitian pada anggaran Hibah di Provinsi Banten tahun 2014-2015, juga mendapatkan temuan sebanyak 144 instansi dan organisasi yang mendapatkan dana hibah tanpa disertai proposal pengajuan dan laporan pencairan, serta ketidakpatuhan administrasi lainnya. Potensi kerugian negara akibat kebocoran dana hibah dan bansos ditaksir sebesar 88 hingga 114,2 miliar rupiah. Disamping menemukan ketidakpatuhan administrasi dalam pelaksanaan hibah dan bansos, FITRA juga menemukan 20 instansi yang mendapatkan dana hibah secara terus menerus dengan tanpa dasar dan ketentuan. ${ }^{4}$

Penelitian ini ingin melihat bagaimana perkembangan politik distribusi program Hibah dan Bansos di Provinsi Banten, terutama setelah berakhirnya masa kepemimpinan Ratu Atut Chosiyah, serta penggantinya, Rano Karno yang secara definitif ditetapkan sebagai Gubernur Banten pada tahun 2015. Provinsi Banten dimasa kepemimpinan Wahidin Halim dan Andika Hazrumy dihadapkan pada sebuah warisan pendistribusian program hibah dan bansos yang brutal, carut marut, serta kerap bermasalah selama bertahun tahun. Distribusi hibah dan bansos dengan berbasis

4 Lihat dalam www.mediaindonesia.com/read/detail/43903-fitra-temukan-korupsi-bansos-banten-114-2-miliar. Diakses pada 10 Juli 2019 Jam 13.18 
kepentingan politik seakan akan sudah menjadi tradisi, terutama menjelang tahun-tahun politik, baik pemilu maupun pilkada.

Tantangan distribusi hibah dan bansos dalam suasana kontestasi politik juga dihadapi oleh Pemerintah Provinsi Banten menjelang tahun politik 2019, dimana ditahun ini diselenggarakan Pemilihan legislatif dan Pemilihan Presiden dan Wakil Presiden secara serentak. Kepemimpinan Provinsi Banten yang terpilih melalui pilkada serentak tahun 2017 bagaimanapun juga merupakan produk politik yang akan selalu dituntut untuk mengakomodasi pendekatan politik dalam beberapa pengambilan kebijakan publik, termasuk dalam kebijakan distribusi hibah dan bansos. Tantangan yang dihadapi Pemerintah Daerah kemudian adalah, apakah pendekatan politik yang menyertai proses pengambilan kebijakan publik, masih dalam koridor tertib administratif serta sesuai dengan aturan perundangan undang yang berlaku.

Dalam perkembangan demokrasi, terdapat sebuah kesepakatan, meskipun tidak dalam bentuk konsensus, bahwa pendekatan otoritas politik (political authority) dapat mendistribusikan sumber daya yang dikelola oleh negara untuk kepentingan masyarakat, selama tidak disertai dengan kontrak untuk memberikan suara dalam kontestasi politik yang bersifat mengikat. ${ }^{5}$ Disamping itu pendekatan politik merupakan aspek yang tidak bisa dihindarkan dalam sebuah proses pengambilan kebijakan publik. Terutama sejak perubahan paradigma administrasi dari orientasi negara (administrasi negara) kepada administrasi yang lebih mengedepankan pendekatan publik (administrasi publik).

\section{Tinjauan Pustaka}

\section{Pendekatan Politik Dalam Kebijakan Publik (Tinjauan Teoritik)}

Penelitian ini hendak menggunakan pendekatan Program Kebijakan Publik Berbias Politik (political diversion of public program) yang merupakan salah satu bentuk dari politik distributif, untuk melihat pola distribusi sumber daya yang dikelola oleh negara, dalam hal ini adalah hibah dan bansos yang dikelola oleh Pemerintah Provinsi Banten. Secara sederhana politik distributif dapat dimaknai sebagai keterlibatan pendekatan politik dalam mengalokasikan sumberdaya dan pelayanan negara kepada masyarakat (Golden dan Min:2012). Konsep politik distributif kemudian juga dipahami sebagai strategi melibatkan partisipasi masyarakat dalam proses alokasi dan distribusi sumber daya yang dimiliki oleh negara (Stokes:2013).

Dalam penerapannya, politik distributif kemudian dibagi menjadi 2, distribusi sumber daya yang terprogram (programmatic) dan yang tak terprogram (non programmatic) (Stokes et.al. 2013; Wardani 2014). Dalam politik distributif terprogram, distribusi sumber daya dilakukan tidak secara langsung untuk mempengaruhi pilihan politik masyarakat, melainkan dengan melibatkan partisipasi warga secara tidak langsung atau melalui perantara, sehingga alokasi sumber daya negara sesuai dengan aspirasi dan kebutuhan warganya. ${ }^{6}$ Kegiatan Musrenbang yang diadakan oleh Pemerintah untuk menyerap aspirasi masyarakat dalam perencanaan pembangunan dapat dikategorikan sebagai politik distributif dalam bentuk programmatic.

Sedangkan distribusi sumber daya tidak terprogram (non programmatic) dibedakan menjadi dua, yaitu bias partisan dan klientilisme (clientelism/machine politics). ${ }^{7}$ Klientilisme

\footnotetext{
${ }^{5}$ Miriam Golden and Brin Min, Distributive Politics Around The World, Annual Review of Political Science, Vol 16, 2013. Hal 73-99

${ }^{6}$ Antonius Saragintan dan Syahrul Hidayat, Politik Pork Barel di Indonesia: Kasus Hibah dan Bantuan Sosial di Provinsi Banten tahun 2011, Jurnal Politik, Vol.2, No 1, Agustus 2016. Hal 139-140.

${ }^{7}$ Susan C.Stokes, Thad Dunning, Marcelo Nazareno and Valeria Brusco, Brokers, Voters, and Clientelism: The Puzzle of Distributive Politics (New York, Cambridge University Press: 2013) hal 7-17
} 
adalah strategi distribusi yang dilakukan oleh kontestan politik, baik individu maupun partai politik dengan memberikan keuntungan material bagi pemilih, dengan tujuan mempengaruhi pilihan politik pemilih. Keuntungan material hanya diberikan apabila pemilih bersedia memberikan suaranya dalam kontestasi politik yang akan dilaksanakan. Yang termasuk dalam klientilisme adalah patronase, jual beli suara (vote buying), serta constituency services. ${ }^{8}$ Klientilisme dapat dilakukan oleh setiap kontestan politik, baik non petahana maupun kontestan petahana atau yang memiliki akses terhadap kekuasaan distribusi sumber daya negara.

Sementara itu distribusi bias partisan dibagi menjadi dua bentuk. Pertama, program atau kebijakan yang bias kepentingan pemilu/politik (electoral diversion of public program) dan kebijakan politik Pork Barrel. ${ }^{9}$ Program Bias Kepentingan Pemilu merupakan bentuk distribusi dan pengalokasian sumber daya kepada individu atau kelompok-kelompok masyarakat dengan harapan dapat mempengaruhi pilihan politik individu atau kelompok masyarakat tersebut untuk memberikan suara kepada partai atau kontestan yang sedang mengikuti pemilu yang memberikan sumber daya tersebut. Bentuk politik distributif bias kepentingan pemilu ini tidak disertai dengan konsekuensi terhadap individu yang menerima sumber daya, meskipun individu tersebut kemudian memberikan suaranya kepada kontestan atau partai lain. (Stokes:2014).

Sedangkan kebijakan politik Pork Barrel adalah pola distribusi sumber daya dengan menitik-beratkan pada wilayah wilayah tertentu yang menjadi basis suara atau diharapkan akan menjadi basis suara bagi kontestan pemilu, baik kandidat individu maupun partai politik. Istilah Pork Barrel pertama kali diperkenalkan oleh John A. Ferejohn dalam karyanya, Pork Barrel Politics: Rivers and Harbors Legislation, 1947-1968, untuk menyebut fenomena distribusi sumber daya negara untuk pemenangan di Congress Amerika Serikat.

Dalam perkembangannya fenomena ini kemudian banyak terjadi di beberapa negara dengan berbagai varian dan ciri khasnya, termasuk di Provinsi Banten di masa akhir kepemimpinan Gubernur Ratu Atut Chosiyah pada tahun 2011. Penelitian yang dilakukan oleh Antonius Saragintan dan Syahrul Hidayat (2016) dalam Politik Pork Barel di Indonesia: Kasus Hibah dan Bantuan Sosial di Provinsi Banten tahun 2011, mengidentifikasi bahwa telah terjadi distribusi sumber daya hibah dan bansos di Provinsi Banten pada tahun 2011 dengan pola Pork Barrel. Pola pemberian alokasi hibah dan bansos dengan memberikan porsi lebih pada basis basis suara tertentu dari petahana ini disertai dengan ketidak tertiban administrasi sehingga melanggar banyak aturan hukum. Sebagaimana telah jamak diketahui publik bahwa salah satu kasus yang menjerat Ratu Atut sebagai tersangka tindak pidana korupsi, selain suap pilkada Lebak adalah temuan pada distribusi hibah dan bansos pada tahun 2011.

Penelitian yang dilakukan oleh Forum Indonesia Untuk Transparansi Anggaran (FITRA) pada tahun 2016, yang berjudul Potensi Penyelewengan Dana Hibah dan Bansos Pada Provinsi Banten Tahun APBD 2014-2015, juga menemukan adanya pola distribusi politik dalam kebijakan hibah dan bansos di Provinsi Banten pada tahun anggaran 2014 hingga 2015. Penelitian ini lebih cenderung mengungkapkan ketidak-tertiban administrasi dan berbagai pelanggaran dalam distribusi hibah dan bansos di tahun tersebut. Namun yang menarik adalah temuan FITRA terkait potensi pelanggaran distribusi hibah dan bansos terjadi pasca tahun politik Pemilu Legislatif 2014 dan menjelang Pilkada Banten 2017. Dari daftar penerima hibah yang dirilis pun lembaga/organisasi yang mendapatkan hibah dan bansos juga potensial untuk dimobilisasi secara politik.

\footnotetext{
${ }^{8}$ Sri Budi Eko Wardani, Transaksi Politik Dalam Pemilu, (Depok, Puskapol UI: 2015) hal 25

${ }^{9}$ Lihat dalam Op.cit., Antonius Saragintan dan Syahrul Hidayat., hal 144-145
} 
Selanjutnya penelitian ini hendak melihat perkembangan kebijakan hibah dan bansos di Provinsi Banten pasca berakhirnya era Ratu Atut Chosiah. Provinsi Banten dibawah kepimpinan Wahidin Halim dan Andika Hazrumy, dalam masa kampanyenya menjanjikan perbaikan birokrasi dalam bentuk reformasi birokrasi untuk memangkas mata rantai korupsi di Banten yang dianggap sudah cukup akut. ${ }^{10}$ Salah satu tantangan yang dihadapi oleh Pemerintah Provinsi Banten dalam upaya melakukan reformasi birokrasi adalah pengelolaan dana Hibah dan Bansos yang hendaknya dilakukan sesuai dengan aturan perundang undangnya yang ada. Sebaran distribusinya juga hendaknya dilakukan sesuai dengan kebutuhan masyarakat Banten, serta dilakukan dengan tertib administrasi, baik pengajuan maupun pelaporan. Penelitian ini diharapkan dapat menjelaskan bagaimana pola bias politik dalam ruang lingkup teori politik distributif diatas terjadi dalam proses distribusi bantuan Hibah dan Bansos.

\section{B. METODE PENELITIAN}

Didalam tulisan ini peneliti mencoba mengulas dengan menggunakan pendekatan metode penelitian kualitatif. Penelitian ini dilakukan dengan cara menganalisis data-data primer yang didapatkan. Data primer diperoleh dari hasil wawancara mendalam dengan narasumber yang dibutuhkan. Narasumber yang diperoleh merupakan pihak yang memahami tentang Kebijakan Hibah Kesejahteraan Rakyat di Banten pada tahun 2019.

\section{HASIL PENELITIAN DAN PEMBAHASAN Distribusi Politik Dalam Kebijakan Hibah Kesejahteraan Rakyat di Banten tahun 2019}

Pemerintah Provinsi Banten merealisasikan dana hibah dan bansos tahun anggaran 2019 sebesar Rp 27.500.000.000, yang diperuntukkan untuk 278 lembaga. Realisasi hibah dan bansos untuk tahun anggaran 2019 ini mengalami penurunan dibanding dengan realisasi hibah dan bansos pada tahun 2018 sebesar Rp 111.951.500.000, yang diperuntukkan untuk 308 lembaga. Sedangkan realisasi hibah dan bansos pada tahun 2018 justru mengamali kenaikan apabila dibandingkan dengan anggaran 2017, sebesar Rp 27.203.800.000, yang hanya tersebar di 27 lembaga penerima.

Penerima bantuan hibah keagamaan pada tahun anggaran 2019 meliputi beberapa organisasi keagamaan, lembaga pendidikan agama, majelis ta'lim, hingga pembangunan sarana dan prasarana pondok pesantren. Terdapat 11 lembaga atau organisasi keagamaan yang menerima hibah 2019, diantaranya adalah pembangunan sekretariat Pimpinan Wilayah Gerakan Pemuda Ansor Provinsi Banten sebesar 1 miliar rupiah, serta partisipasi dalam pembangunan gedung sekretariat Persatuan Guru Madrasah Ibtidaiyah (PGMI) Provinsi Banten, sebesar 50 juta rupiah. Selain itu terdapat 134 lembaga pendidikan keagamaan serta 57 majelis ta'lim yang ikut mendapatkan kucuran dana hibah, yang sebagian besar diperuntukan untuk pembangunan sarana dan prasarana.

Skema hibah dan bansos tahun anggaran 2019 juga menyertakan bantuan operasional untuk pondok pesantren di Banten. Sebanyak 3.079 pesantren mendapatkan bantuan hibah sebesar 30 juta rupiah per pesantren. Nominal hibah yang diberikan pada tahun 2019 mengalami kenaikan dibanding tahun tahun sebelumnya yang hanya sebesar 20 juta rupiah. Dengan demikian realisasi anggaran hibah untuk operasional pondok pesantren pada tahun 2019 sebesar Rp 92.370.000.000. Maka, total realisasi anggaran Pemerintah Provinsi Banten melalui Biro Kesejahteraan Rakyat pada tahun anggaran 2019 sebesar Rp 119.870.000.000.

\footnotetext{
${ }^{10}$ Lihat dalam Visi dan Misi Kandidat Gubernur dan Wakil Gubernur Provinsi Banten dalam Pilkada Provinsi Banten tahun 2017
} 
Penerima hibah Provinsi Banten tahun 2019 tersebar di 8 kabupaten/kota dengan jumlah yang beragam di masing masing wilayah tersebut. Penerima hibah terbanyak merupakan lembaga atau organisasi yang berada di wilayah Kabupaten Tangerang dengan 84 organisasi/ lembaga penerima. Penerima terbanyak kedua berada di Kabupaten Lebak, dimana di kabupaten paling selatan Provinsi Banten ini terdapat 71 lembaga/organisasi penerima hibah. Selanjutnya di Kabupaten Pandeglang terdapat 52 lembaga/organisasi penerima serta Kabupaten Serang sebanyak 50 organisasi/lembaga penerima dan Kota Serang sebanyak 35 lembaga.

Yang menarik dari penelitian ini adalah temuan penerima hibah Provinsi Banten di tiga kota, yaitu Kota Cilegon, Kota Tangerang Selatan, serta Kota Tangerang. Di Kota Cilegon hanya terdapat terdapat 1 penerima, sedangkan kota Tangerang Selatan hanya terdapat 3 penerima. Sedangkan Kota Tangerang, sebagai kota asal dari Gubernur Banten periode 2017-2022, Wahidin Halim, hanya terdapat 5 lembaga/organisasi penerima. Sedangkan penerima hibah operasional pesantren sebesar 30 juta/pesantren, sebanyak 3079 pesantren, tersebar di 8 kabupaten/kota secara merata. Hal ini mengingat kebijakan hibah operasional pesantren diberikan kepada setiap pesantren yang ada di provinsi Banten secara merata tanpa mempertimbangkan letak geografis serta kondisi sosial-ekonomi pesantren.

Apabila kita bandingkan program hibah Kesejahteraan Rakyat/ Biro Kesra tahun 2019 dengan hibah serupa pada tahun 2018, maka ditemukan pola yang tidak jauh berbeda terkait sebaran penerima hibah berdasarkan wilayah. Pada program hibah Kesra 2018. Kabupaten Lebak dan Pandeglang masih menjadi wilayah dengan jumlah penerima hibah terbanyak di Provinsi Banten. Terdapat 59 lembaga/organisasi penerima hibah di Kabupaten Lebak, sedangkan di Kabupaten Pandeglang sebanyak 64 lembaga penerima.

Sedangkan Kota Tangerang Selatan dan Kota Cilegon adalah kota dengan jumlah penerima terendah, dimana di Kota Tangerang Selatan hanya terdapat 4 lembaga/organisasi penerima, sedangkan di Kota Cilegon hanya terdapat 8 lembaga/organisasi penerima. Temuan yang berbeda terdapat di Kota Tangerang, dimana jumlah lembaga/organisasi penerima hibah jauh lebih banyak dibanding tahun setelahnya, yaitu 55 lembaga.

Apabila dilihat dari sebaran penerima Hibah Kesejahteraan Rakyat Provinsi Banten dalam 2 tahun terakhir, yaitu 2018 hingga 2019, atau 2 tahun pertama kepemimpinan Gubernur dan Wakil Gubernur Banten, Wahidin Halim-Andika Hazrumy, penelitian ini tidak menemukan pola Pork Barrel sebagaimana pernah ditemukan dalam beberapa penelitian sebelumnya terkait dengan pola distribusi sumber daya negara di Provinsi Banten. Mengingat wilayah-wilayah terbanyak yang menerima hibah dari Provinsi Banten, yaitu Kabupaten Lebak dan Kabupaten Pandeglang notabene nya bukanlah kantong suara, baik dari Wahidin Halim sebagai Gubernur, maupun Andika Hazrumy sebagai Wakil Gubernur. Bahkan portofolio elektoral dari kedua pimpinan Provinsi Banten tersebut, terutama Wahidin Halim, menunjukkan bahwa di kedua wilayah tersebut selalu mengalami kekalahan dalam setiap kontestasi pilkada yang pernah diikuti, baik pilkada Provinsi Banten tahun 2012 maupun Pilkada Provinsi Banten tahun 2017.

Sebaliknya, wilayah Tangerang Raya, terutama kota Tangerang merupakan basis suara dari Wahidin Halim, dimana Gubernur Banten periode 2017-2022 ini pernah menjabat sebagai walikota Tangerang selama 2 periode berturut-turut. Demikian juga dengan Kota Tangerang Selatan merupakan basis suara keluarga besar Andika Hazrumy mengingat bibi ipar Wakil Gubernur Banten periode 2017-2022 ini, yaitu Airin Rachmy Diani, merupakan walikota Tangerang Selatan selama 2 periode berturut-turut. Kota Tangerang Selatan juga merupakan basis suara keluarga besar Ratu Atut Chosiah, ibu dari Andika Hazrumy, dalam setiap kontestasi politik, baik pemilu legislatif maupun pemilihan kepala daerah. 
Dalam Pilkada Provinsi Banten tahun 2017, yang mengantarkan pasangan Wahidin HalimAndika Hazrumy sebagai Gubernur dan Wakil Gubernur Banten terpilih periode 2017-2022, perolehan suara di Kota Tangerang memegang peranan kunci dalam kemenangan pasangan ini. Pasangan Wahidin Halim-Andika Hazrumy mengalami kekalahan di 6 kabupaten/kota, dan hanya memenangkan perolehan suara di 2 wilayah, yaitu Kabupaten Serang dan Kota Tangerang. Perolehan suara di Kota Tangerang merupakan perolehan yang paling signifikan karena dianggap mampu menutupi kekalahan di 6 kabupaten/kota yang lain.

Tabel:2

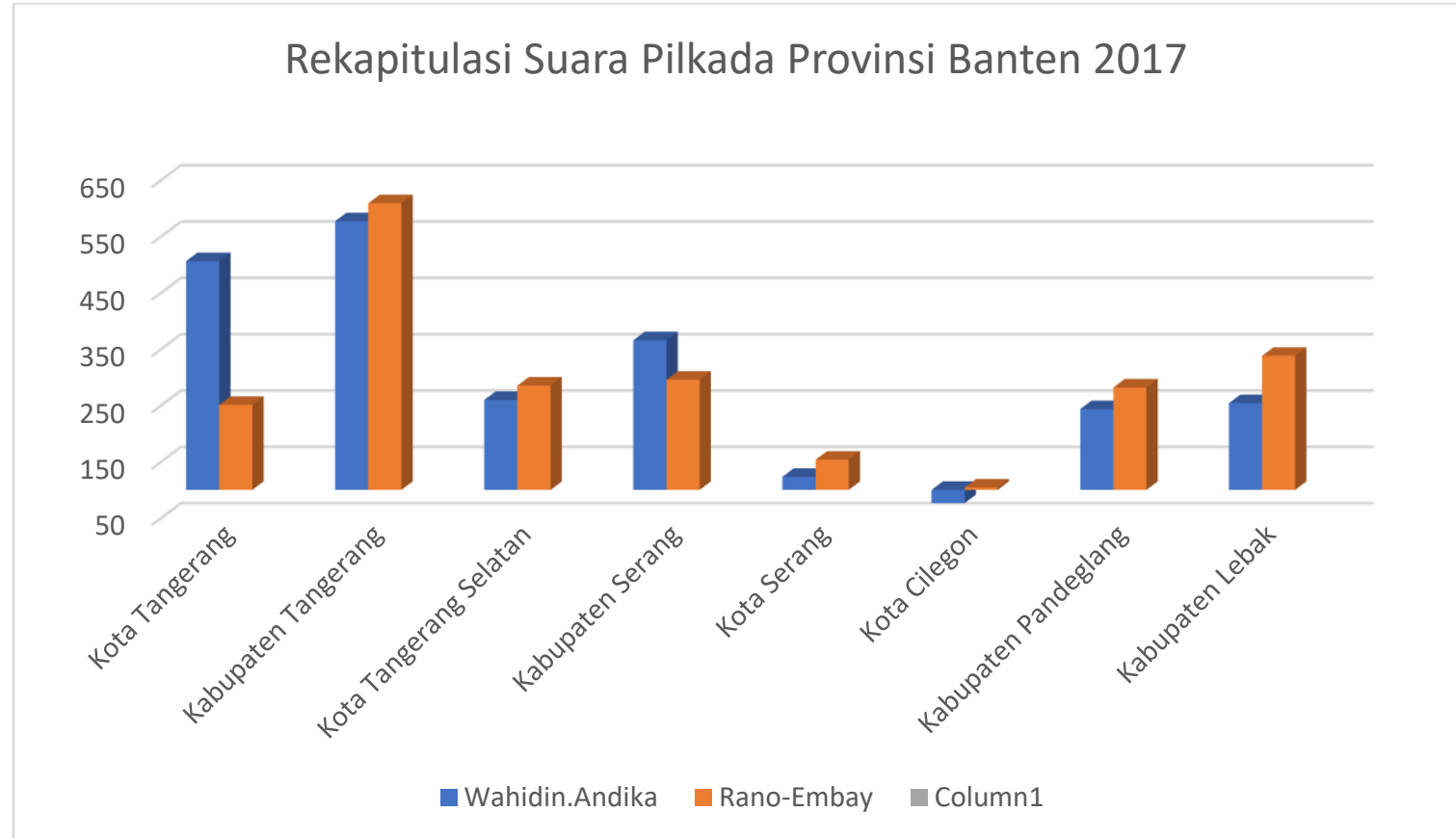

Sebaran distribusi hibah Kesejahteraan Rakyat Provinsi Banten di 2 tahun pertama kepemimpinan Gubernur Banten menunjukkan bahwa wilayah yang tidak menjadi basis suara dari Wahidin Halim justru mendapatkan porsi lebih banyak dalam distribusi hibah. Sedangkan wilayah yang menjadi basis suara, khususnya Kota Tangerang justru mendapatkan porsi yang jauh lebih sedikit dalam distribusi hibah.

Dalam wawancara mendalam (depth interview) dengan Gubenur Banten, Wahidin Halim, peneliti menemukan bahwa salah satu semangat dari kebijakan distribusi sumber daya negara, baik hibah Kesra, hibah pendidikan, bahkan bantuan Dana Perimbangan Pemerintah Provinsi kepada Pemerintah Kabupaten/Kota di Banten adalah dalam rangka memperkecil disparitas ekonomi dan kemampuan keuangan antara wilayah Utara dan Selatan. Dari data statistik Provinsi Banten dapat diketahui bahwa kesenjangan ekonomi antara wilayah Utara Provinsi Banten, yang meliputi Tangerang Raya, dan wilayah selatan Provinsi Banten, terutama Kabupaten Serang, Lebak, dan Pandeglang, sangatlah tinggi. Kesenjangan dapat dilihat dari beberapa variabel, seperti angka kemiskinan, indeks pembangunan manusia, pertumbuhan ekonomi, dan lain-lain, hingga besaran Pendapatan Asli Daerah (PAD) masing masing kabupaten/kota. ${ }^{11}$

Sebaran distribusi hibah, baik pada tahun 2019 maupun 2020 dapat dijadikan indikator untuk menilai keseriusan Pemerintah Provinsi dalam memperkecil kesenjangan ekonomi antara Utara dan Selatan tersebut. Selain itu, besar bantuan keuangan dalam skema Bantuan Keuangan

${ }^{11}$ Wawancara dengan Gubernur Banten, Wahidin Halim, mengenai topik penelitian ini dilakukan dari bulan Mei hingga Agustus 2020, di Rumah DInas Gubernur Banten, Kota Serang, Provinsi Banten. 
Provinsi kepada Kabupaten/Kota dapat juga menjadi indikator penting dalam upaya pemerataan pembangunan di wilayah Banten

Tabel:6

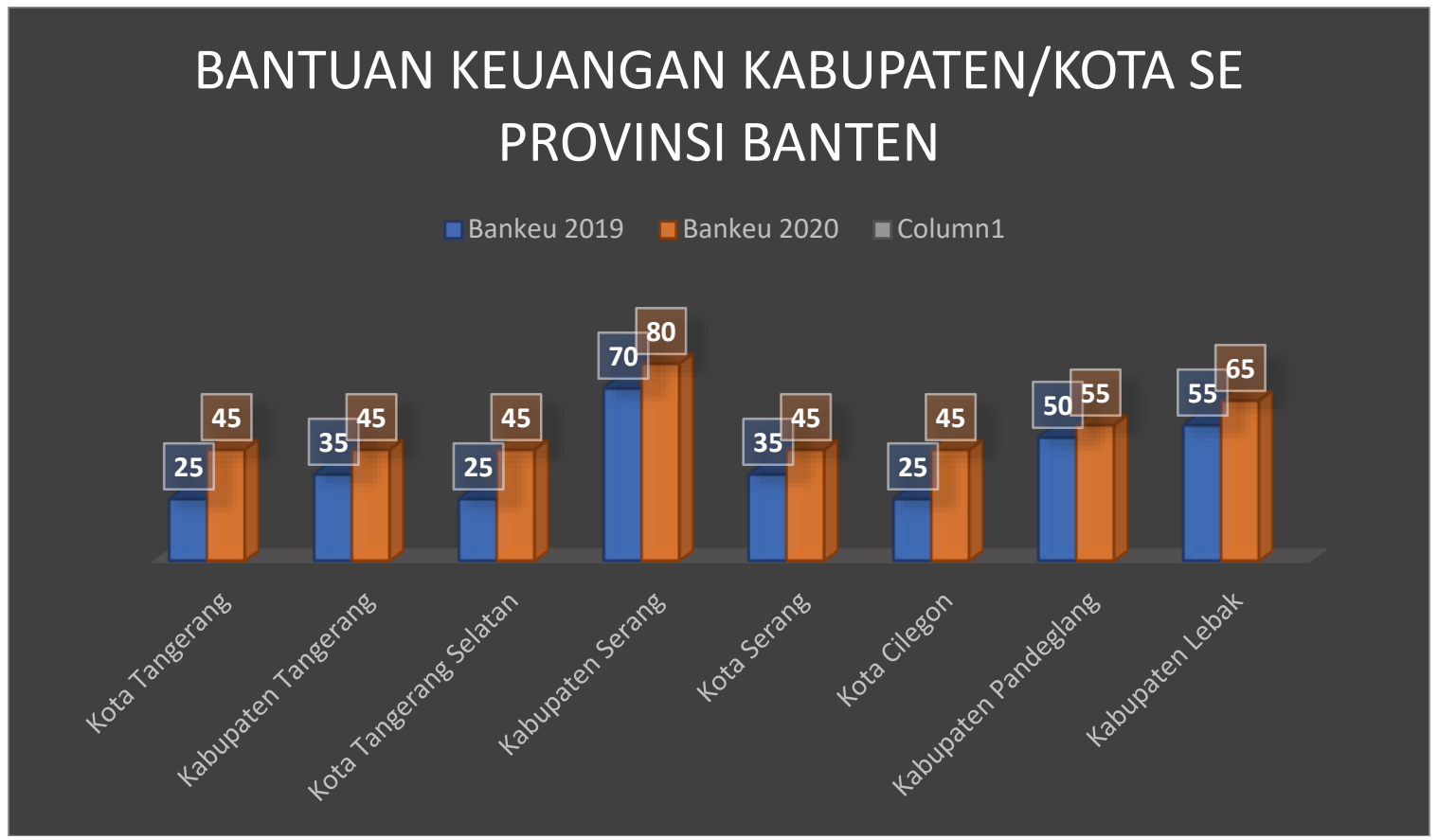

Terkait dengan keuntungan politik yang bisa didapat dari distribusi sumber daya negara tersebut, Wahidin Halim juga mengungkapkan bahwa insentif elektoral sebagai efek dari distribusi hibah tersebut hanyalah bonus dari meningkatnya kepuasan publik terhadap kinerja Pemerintah Provinsi Banten, terutama dalam hal pemerataan pembangunan. Tidak dapat dipungkiri adanya harapan, bahwa meningkatnya distribusi hibah di wilayah yang tidak menjadi basis suara diharapkan dapat meningkatkan tingkat keterpilihan petahana dalam kontestasi politik yang akan datang. Namun motivasi politik tersebut tentunya tidak mengurangi kualitas penyelenggaraan distribusi hibah yang harus sesuai dengan kebutuhan pemerataan pembangunan serta dilakukan dengan sesuai dengan prosedur dan perundang-undangan yang berlaku.

Hal senada disampaikan oleh plt Biro Kesejahteraan Rakyat Provinsi Banten, Ade Ariyanto, bahwa distribusi Hibah Kesejahteraan Rakyat Provinsi Banten pada saat ini sepenuhnya berbasis pengajuan proposal serta telah melalui seleksi kelayakan. Artinya, penerima hibah pada tahun 2018 hingga 2019 adalah organisasi/lembaga yang telah diseleksi berdasarkan asas kelayakan, kebutuhan dan manfaat. Pelaksanaan program hibah pun diawasi secara berkala oleh inspektorat serta dilaporkan kepada Badan Pemeriksa Keuangan.

\section{KESIMPULAN}

Berdasarkan kajian dan observasi mendalam terhadap data-data yang tersedia, penelitian ini menghasilkan beberapa temuan yang berupa:

a. Distribusi hibah Kesejahteraan Rakyat Provinsi Banten pada tahun anggaran 2018-2019 tersebar di daerah-daerah yang bukan menjadi kantong suara dari kepala daerah yang sedang berkuasa.

b. Penelitian ini tidak menemukan pola pork barrel dalam distribusi hibah Kesejahteraan Rakyat (Kesra) Pemerintah Provinsi Banten pada tahun anggaran 2018-2019. Pola pork 
barrel ditemukan dalam beberapa penelitian tentang distibusi hibah dan bansos di Provinsi Banten pada tahun 2011 dan 2014, dimana ditemukan indikasi bahwa distribusi hibah dan bansos sangat terkait dengan kontestasi politik yang telah atau akan berlangsung.

c. Pendekatan politik yang dapat digunakan untuk memahami distribusi hibah Kesejahteraan Rakyat (Kesra) tahun anggaran 2018-2019 adalah electoral diversion of public program, dimana distribusi sumber daya negara tidak terkait dengan perolehan suara dalam kontestasi politik sebelumnya. Namun ada harapan bahwa distribusi sumber daya negara dapat meningkatkan elektabilitas pada kontestasi politik yang akan datang.

\section{E. DAFTAR PUSTAKA}

Antonius Saragintan dan Syahrul Hidayat, Politik Pork Barel di Indonesia: Kasus Hibah dan Bantuan Sosial di Provinsi Banten tahun 2011, Jurnal Politik, Vol.2, No 1, Agustus 2016.

Hasan Basri, Using Qualitative Research in Accounting and Management Studies: Not a New Agenda, Journal of US-China Public Administration, October 2014, Vol. 11, No. 10.

John A. Ferejohn, Pork Barrel Politics: Rivers and Harbors Legislation, 1947-1968, (Stanford, Stanford University Press: 1974)

Mohamed, Z. M., Abdul Majid, A. H., \& Ahmad, N, Tapping new possibility in accounting research, in qualitative research in accounting, Malaysian case. (Universiti Kebangsaan Malaysia, Kuala Lumpur, Malaysia: 2010)

Miriam Golden and Brin Min, Distributive Politics Around The World, Annual Review of Political Science, Vol 16, 2013

Susan C.Stokes, Thad Dunning, Marcelo Nazareno and Valeria Brusco, Brokers, Voters, and Clientelism: The Puzzle of Distributive Politics (New York, Cambridge University Press: 2013).

Sri Budi Eko Wardani, Transaksi Politik Dalam Pemilu, (Depok, Puskapol UI: 2015). Kevin McCusker and Serdar Gunaydin, research using qualitative, quantitative, or mixed methods and choice based on research, (Published in Perfusion (30) 7: November 2015) 